\title{
Pemberdayaan Masyarakat Pengrajin Songket Silungkang di Kota Sawahlunto Sumatera Barat
}

Sonya Melinda ${ }^{1}$, Rinel Fitlayeni ${ }^{2}$, Ariesta Ariesta $^{3}$

${ }^{1,3}$ Universitas PGRI Sumatera Barat, ${ }^{2}$ Universitas Padjadjaran

Email: rin31_inzaghi@yahoo.co.id

\begin{abstract}
Abstrak
Songket Silungkang merupakan salah satu warisan budaya daerah Kota Sawahlunto yang sudah terkenal di Indonesia hingga mancanegara. Songket Silungkang memiliki ciri khas pada ragam hias songket yang menjadi salah satu faktor terpenting dalam pembuatannya. Selain itu songket juga merupakan sentra produksi unggulan lokal di Kota Sawahlunto, sehingga butuh dilestarikan kerajinan ini melalui pemberdayaan ekonomi. Salah satu bentuk pemberdayaan dengan dilakukan pelatihan tenun songket yang dilakukan oleh Dinas Perindustrian Perdagangan Koperasi (Koperindag) \& UPTD Tekstil Kota Sawahlunto. Penelitian ini bertujuan untuk mendeskripsikan tujuan pemberdayaan ekonomi masyarakat pengrajin songket desa Muaro Kalaban, Kecamatan Silungkang serta strategi pemasaran tenun Silungkang tersebut. Penelitian ini menggunakan teori Fungsionalisme Struktural Talcott Parson. Penelitian ini termasuk jenis penelitian kualitatif dengan tipe studi kasus. Informan penelitian ini berjumlah 7 orang yang terdiri dari Kepala Bidang Perindustrian Dinas Koperindag Kota Sawahlunto, Kepala Pelatihan UPTD Kota Sawahlunto, peserta pelatihan tenun songket Kecamatan Silungkang, peserta yang produktif bertenun sampai sekarang. Metode pengumpulan data yang digunakan yaitu observasi dan wawancara. Hasil penelitian ini menunjukkan bahwa pemberdayaan yang dilakukan oleh Koperindag dan UPTD melalui pelatihan tenun songket bertujuan untuk; 1) meningkatkan ekonomi pengrajin tenun songket, 2) meningkatkan produksi songket Silungkang, 3) melestarikan karya seni. Sedangkan strategi pemasaran yang dilakukan oleh masyarakat dengan 1) membangun relasi dengan toko-toko grosir, 2) pemasaran secara online.
\end{abstract}

\section{Kata Kunci: Ekonomi Masyarakat, Pemberdayaan, Pengrajin Songket}

\begin{abstract}
Songket Silungkang is one of the cultural heritages of the City of Sawahlunto which is well known in Indonesia and abroad. Songket Silungkang has a characteristic in songket decoration which is one of the most important factors in its manufacture. In addition, songket is also a local superior production center in Sawahlunto City, so this craft needs to be preserved through economic empowerment. One form of empowerment is by conducting songket weaving training conducted by the Cooperative Trade Industry Service (Koperindag) \& Textile UPTD Sawahlunto City. This study aims to describe the objectives of the economic empowerment of the songket craftsmen in Muaro Kalaban village, Silungkang district and the marketing strategy of the Silungkang weaving. This research uses Talcott Parson's Structural Functionalism theory. This research is a type of qualitative research with a case study type. The informants of this research consisted of 7 people consisting of the Head of the Industrial Division of the Koperindag Office of Sawahlunto City, the Head of the UPTD Training of Sawahlunto City, the participants of the songket weaving training in Silungkang sub-district, the participants who were productive in weaving until now. Data collection methods used are observation and interviews. The results of this study indicate that the empowerment carried out by Koperindag and UPTD through songket weaving training aims to; 1) improve the economy of songket weaving craftsmen, 2) increase the production of short songket, 3) preserve works of art. While the marketing strategy is carried out by the community by 1) building relationships with wholesale shops, 2) online marketing.
\end{abstract}

Keywords: Community Economy, Empowerment, Songket Craftsmen. 


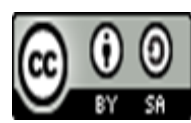

\section{Pendahuluan}

Sumatera Barat merupakan salah satu provinsi yang memiliki tingkat kebudayaan yang tinggi, masyarakat Sumatera Barat dikenal sebagai masyarakat yang memegang teguh adat istiadatnya. Di Sumatera Barat adat budaya merupakan salah satu pokok pemikiran penting dalam masyarakatnya, hal itu tercermin dalam semboyan adat "tak lakang dek peneh, tak lapuak dek hujan" artinya adat tersebut tetap akan bertahan tak tergerus oleh pengaruh zaman. Pribahasa ini lebih mengumpamakan pada adat matrilineal Minangkabau yang selalu bertahan terhadap berbagai gempuran budaya dari luar, seperti budaya Islam, barat pada zaman penjajahan, maupun budaya dominan lainnya di Indonesia.

Keunikan dan keberagaman budaya Minangkabau juga terasa begitu kuat disalah satu kota di Provinsi Sumatera Barat, yaitu Kota Sawahlunto (Utami, 2016a). Kota Sawahlunto yang biasa disebut dengan sebutan kota wisata tambang yang berbudaya dengan pariwisata warisan tambang batu bara sebagai ciri khas daerah, menjadikan pekerjaan masyarakat dominan dalam sektor pariwisata dan pertambangan. Selain itu tenun songket juga menjadi pekerjaan banyak masyarakat Sawahlunto khususnya di Kecamatan Silungkang. Songket merupakan simbol dan idenditas masyarakat Silungkang, dan juga sebagai sumber pendapatan dan kebanggaan masyarakat Silungkang.

Songket Silungkang merupakan salah satu warisan penting bagi masyarakat Sawahlunto yang sudah terkenal di Indonesia hingga mancanegara. Songket Silungkang memiliki ciri khas pada ragam hias songket yang menjadi salah satu faktor terpenting dalam pembuatannya. Ragam hias yang diciptakan oleh songket Silungkang mewakili simbol atau makna tertentu tentang adat istiadat dan kehidupan masyarakat Silungkang. Motif songket Silungkang tersebut terinspirasi dari alam terutama dengan mengambil dari bentuk dasar dari tumbuh-tumbuhan dan binatang. Proses pembuatan kain songket dikerjakan secara turun temurun oleh masyarakat Silungkang (Syafrini et al., 2021).

Kata songket berasal dari istilah sungkit dalam Bahasa Melayu dan Bahasa Indonesia, yang berarti "mengait" atau "mencungkil". Hal ini berkaitan dengan metode pembuatannya; mengaitkan dan mengambil sejumput kain tenun, dan kemudian menyelipkan benang emas. Selain itu, menurut sementara orang, kata songket juga mungkin berasal dari kata "songka", songkok khas Palembang yang dipercaya pertama kalinya kebiasaan menenun dengan benang emas dimulai. Istilah menyongket berarti 'menenun dengan benang emas dan perak (Rodgers, 2007). Penenunan songket secara sejarah dikaitkan dengan kawasan permukiman dan budaya Melayu, dan menurut sementara orang teknik ini diperkenalkan oleh pedagang India atau Arab (Rodgers, 2007). Tenun songket merupakan proses pembuatan kain jadi yang berasal dari benang emas atau benang perak yang dibuat dengan menggunakan alat yang masih tradisional dan masih dipekerjakan oleh tangan manusia (Wijaya, 2017).

Ilmu menenun yang dimiliki oleh orang tua diwariskan turun temurun ke anaknya sehingga kain ini tidak hilang seiring dengan perkembangan zaman (Mardatillah et al., 2020). Pembuatan songket tersebut tidak hanya dilakukan oleh perempuan tetapi laki-laki juga ikut menenun kain songket walaupun tidak sebanyak perempuan. Dahulu Songket Silungkang dibuat menjadi selendang yang digunakan oleh orang-orang terpandang seperti datuk, keluarga datuk, penghulu, dan orang terkemuka lainnya. Karena harganya yang relatif mahal, hanya orang orang kaya yang mampu membelinya (Utami, 2016). 
Pemerintah Kota Sawahlunto memiliki kewenangan hak dan kewajiban untuk mengatur sendiri urusan pemerintahan daerahnya sebagaimana diatur oleh Undang Undang Nomor 32 Tahun 2004 tentang pemerintah daerah. Begitu juga dengan menggalakan dan mengembangkan Usaha Mikro Kecil Menengah (UKKM) daerahnya yang salah satunya terhadap kerajinan Tenun Songket Silungkang. Salah satu dinas yang mengurus bagian ini adalah Dinas perindustrian perdagangan koperasi \& UMKM (Koperindag) Kota Sawahlunto.

Koperindag menjalan tugas untuk melaksanakan urusan pemerintahan bidang perindustrian, pemerintahan, perdagangan, koperasi, usaha kecil dan menengah. Lembaga ini dihapkan dapat mampu memberikan peran aktif dalam upaya perwujudan Kota Sawahlunto untuk menjadi kompetitif dan mandiri, melalui peningkatan SDM aparatur, manajemen kerja dan sistem kerja. Selain itu lembaga ini juga diharapkan dapat mendorong pertumbuhan sentra produksi unggulan lokal berbasis sumber daya lokal terutama pariwisata dan kerajinan.

Adanya lembaga ini diharapkan dapat menjadi salah satu sarana bagi pemberdayaan ekonomi kerajinan Songket Silungkang. Pemberdayaan dalam kamus besar Bahasa Indonesia sebagai kata nomina (kata benda) yang berarti proses, cara, perbuatan, memberdayakan. Pemberdayaan masyarakat ialah proses pembangunan yang membuat masyarakat berinisiatif untuk memulai proses kegiatan sosial dalam memperbaiki situasi dan kondisi diri sendiri. Pemberdayaan masyarakat hanya bisa terjadi apabila masyarakat itu sendiri ikut pada partisipasi. Jadi pada intinya kata kunci dari pemberdayaan adalah meliputi: proses pembangunan, masyarakat berinisiatif, memperbaiki situasi kondisi diri sendiri. Dengan kata lain keberhasilan dari program atau kegiatan pemberdayaan masyarakat tidak hanya ditentukan oleh pihak yang melakukan pemberdayaan, tetapi juga aktifnya pihak yang diberdayakan untuk mengubah situasi dan kondisi menjadi lebih baik dari sebelumnya (Maryani, 2019:8). Salah satunya masyarakat Kecamatan Silungkang, Kota Sawahlunto dengan memberikan pelatihan tenun kepada masyarakat. Pelatihan tenun yang diberikan karena tingginya minat masyarakat akan kain tenun songket Silungkang yang sudah terkenal dari dahulu. Selain itu masih rendah keterampilan masyarakat dalam bertenun songket, diharapkan dengan bertenun bisa meningkatkan perekonomian masyarakat terutama bagi ibu-ibu rumah tangga.

Berdasarkan data penerima bantuan alat tenun songket pada tahun 2019, Desa Muarokalaban, Kecamatan Silungkang yang paling banyak menerima bantuan dari Dinas Koperindag yakni sebanyak 28 orang. Untuk lebih jelasnya dapat dilihat pada tabel 1.

Tabel 1. Data Desa Penerimaan Bantuan Alat Tenun Songket Di Kecamatan Silungkang

\begin{tabular}{cccc}
\hline No & Nama Desa & Jumlah & Keterangan \\
\hline 1 & Desa Silungkang Oso & 6 Orang & Aktif \\
\hline 2 & Desa Silungkang Duo & 9 Orang & Aktif \\
\hline 3 & Desa Silungkang Tigo & 14 Orang & Aktif \\
\hline 4 & Desa Muarokalaban & 28 Orang & Aktif \\
\hline & Jumlah & 57 Orang & \\
\hline
\end{tabular}

Sumber: Dinas KOPERINDAG- UPTD IKM Kota Sawahlunto 2019

Berdasarkan tabel 1.1 bahwa dibandingkan dengan desa lainnya, Desa Muaro Kelaban paling banyak menerima bantuan alat tenun songket. Alat tenun songket yang didapatkan oleh masyarakat karena mereka mengikuti pelatihan yang dilakukan doleh Dinas Koperindag UPTD Tekstil Kota Sawahlunto. Pelatihan yang diberikan bertujuan agar masyarakat bisa berdikari sendiri. Dalam penelitian ini, fokusnya ke Desa Muaro Kelaban Kecamatan Silungkang karena daerah tersebut yang paling banyak mengikuti pelatihan. 
Tulisan ini bertujuan untuk membahas tentang tujuan pemberdayaan masyarakat pengrajin songket di Desa Muaro Kalaban Kecamatan Silungkang, Sawahlunto serta strategi yang dilakukan oleh masyarakat dalam memasarkan tenun silungkang tersebut. Masalah ini menarik untuk dikaji, karena prinsip pemberdayaan masyarakat tidak hanya dapat mengembangkan potensi ekonomi rakyat, tetapi juga harkat martabat, rasa percaya diri serta terpelihara tatanan nilai budaya setempat. Pemberdayaan sebagai konsep sosial budaya yang implementatif dalam pembangunan yang berpusat untuk masyarakat, tidak hanya menumbuhkan dan mengembangkan nilai tambah ekonomis, tetapi juga nilai tambah sosial budaya.

Pemberdayaan masyarakat ialah proses pembangunan yang membuat masyarakat berinisiatif untuk memulai proses kegiatan sosial dalam memperbaiki situasi dan kondisi diri sendiri. Pemberdayaan masyarakat hanya bisa terjadi apabila masyarakat itu sendiri ikut pada partisipasi. Jadi pada intinya kata kunci dari pemberdayaan adalah meliputi: proses pembangunan, masyarakat berinisiatif, memperbaiki situasi kondisi diri sendiri. Dengan kata lain keberhasilan dari program atau kegiatan pemberdayaan masyarakat tidak hanya ditentukan oleh pihak yang melakukan pemberdayaan, tetapi juga oleh aktifnya pihak yang di berdayakan untuk mengubah situasi dan kondisi menjadi lebih baik dari sebelumnya (Maryani, 2019).

Studi terkait dengan tenun songket pernah dilakukan oleh beberapa peneliti sebelumnya, seperti Efendi (2019) dengan judul "Peranan Industri Songket dalam Meningkatkan Pendapatan Rumah Tangga Pengrajin di Nagari Halaban Kabupaten Lima Puluh Kota". Hasil penelitian menjelaskan bahwa mayoritas pengrajin songket telah menekuni pekerjaan sebagai pengrajin 11-20 tahun. Rumah tangga pengrajin songket mayoritas bekerja sebagai petani, usaha tani, pedagang, buruh dan swasta. Industri songket ini memberikan pendapatan rata-rata lebih tinggi dibandingkan usaha tani dalam komposisi pendapatan rumah tangga. Hal ini menunjukkan bahwa industri songket memiliki peran penting dalam meningkatkan ekonomi rumah tangga di Nagari Halaban. Kemudian penelitian Haryani Harsari (2018) juga mengkaji terkait "Pembinaan Sentra Produksi Tenun Songket Unggan oleh Pemerintah Kabupaten Sijunjung". Hasil penelitian menunjukkan bahwa pembinaan sentra tenun songket unggan oleh pemerintah di Kabupaten Sijunjung sudah sedikit maksimal, terlihat dari peran fasilitator, regulator dan juga katalisator. Sedangkan kendala dalam pengembangan sentra tenun songket unggan di Kecamatan Sumpur Kudus Kabupaten Sijunjung yakni dari keterbatasan anggaran (modal), kurangnya manajemen SDM, lemahnya jaringan usaha, keterbatasan akses pasar serta kesulitan distribusi dan pengadaan bahan baku (Harsari, 2018). Sedangkan Sinta Amadhani mengkaji "Kendala-kendala pada Industri Kerajinan Tenun Songket di Nagari Unggan Kecamatan Sumpur Kudus Kabupaten Sijunjung”. Hasil penelitian menunjukkan bahwa ada beberapa kendala yang dihadapi oleh industri kerajinan tenun songket Unggan yakni terletak pada modal, sumber daya manusia, transportasi, bahan baku, proses bertenun serta kendala dalam bidang pemasaran (Amadani, 2015).

Meskipun penelitian di atas sama-sama mengkaji tenun songket, namun penekanannya berbeda dengan penelitian ini. Herlina Effendi (2019) lebih menekankan pada industri songket berperan dalam meningkatkan ekonomi rumah tangga di Nagari Halaban. Haryani Harsani (2018) menitik beratkan beberapa kendala yang dihadapi oleh Pemerintah Sumpur Kudus dalam melakukan proses pembinaan. Sedangkan Sinta Ramadhani (2015), fokus kajiannya pengrajin tenun dalam menjalankan industri tenun songket menghadapi kendala. Sementara penelitian ini lebih terfokus pada pemberdayaan masyarakat pengrajin tenun songket Silungkang, dalam upaya meningkatkan produktivitas dan kreativitas mereka. Dengan demikian penelitian ini memiliki kebaruan dan kontribusi secara akademis dan paraktis, terutama pada aspek pemberdayaan masyarakat sebagai salah satu tujuan pembangunan nasional. 


\section{Metode Penelitian}

Penelitian ini menggunakan pendekatan penelitian kualitatif. Pendekatan kualitatif dapat digunakan untuk mendapatkan data yang lebih akurat dan mendalam yang datanya mengandung makna. Makna yang dimaksud sebenarnya yaitu data yang merupakan suatu nilai di balik data yang ada dan terlihat. Pendekatan kualitatif adalah penelitian yang berlandaskan pada filsafat postpositivisme yang digunakan untuk meneliti pada kondisi obyek yang alamiah, dimana peneliti sebagai instrumen kunci, analisis data bersifat induktif (Sugiyono,2012). Adapun tipe penelitian yang digunakan adalah studi kasus.

Informan penelitian adalah orang yang memberikan informasi baik tentang dirinya ataupun orang lain atau suatu kejadian atau suatu hal kepada peneliti atau tentang dirinya maupun orang lain atau suatu kejadian (Afrizal, 2008). Teknik pemilihan informan penelitian yaitu dengan cara purposive sampling. Purposive sampling adalah teknik penentuan sampel dengan pertimbangan tertentu (Denzin \& Lincoln, 2009). Dalam upaya merumuskan data yang relevan, teknik pemilihan informan dengan purposive sampling, informan ditetapkan secara sengaja oleh peneliti sendiri. Dalam hal ini peneliti harus mengetahui bahwa orang-orang yang dipilihnya dapat memberikan informasi yang diinginkan sesuai dengan permasalahan penelitian. Adapun jumlah informan dalam penelitian ini berjumlah 7 orang yang terdiri dari Kepala Bidang Industri, Kepala UPTD Tekstil serta peserta pelatihan tenun songket.

Jenis data yang digunakan dalam penelitian ini adalah data primer dan data sekunder. Data primer adalah data yang dapat diperoleh langsung dari lapangan.data primer dari peneltian ini adalah data yang diperoleh dari wawancara dan observasi dari masyarakat yang mengikuti pelatihan tenun songket di Desa Muarokalaban, Kecamatan Silungkang. Proses wawancara dilakukan di kantor dan rumah informan. Sebelum melakukan proses wawancara, peneliti menghubungi terlebih dahulu untuk membuat janji. Sedangkan data sekunder dimana peneliti mendapatkan data yang diperoleh dari data yang diperoleh berupa data daftar peserta pelatihan tenun, data rekapulasi bantuan alat tenun.

Unit analisis adalah sesuatu yang berkaitan dengan fokus yang diteliti. Unit analisis merupakan suatu penelitian yang dapat berupa benda, individu, kelompok, wilayah, dan waktu tertentu sesuai dengan fokus penelitiannya, sebuah penelitian, menentukan unit analisis diperlukan agar peneliti dapat mengetahui dan menentukan masalah dari penelitian tersebut (Arikunto, 2006). Unit analisis data dalam penelitian ini adalah kelompok, yaitu masyarakat yang mengikuti pelatihan tenun songket di Muarokalaban Kecamatan Silungkang.

\section{Hasil dan Pembahasan}

\section{Tujuan Pemberdayaan Pengrajin Tenun Silungkang}

Berdasarkan hasil penelitian ditemukan bahwa salah satu bentuk pemberdayaan yang dilakukan kepada pengrajin Tenun Silungkang adalah pelatihan pembuatan tenun yang difasilitasi oleh Dinas Koperindag Sawahlunto. Pelatihan ini dilakukan sebagai salah satu upaya mengurangi angka kemiskinan dikalangan ibu-ibu rumah tangga di Sawahlunto. Selain itu pemberdayaan ini juga dilakukan sebagai upaya meningkatkan jumlah produksi Tenun Silungkang, karena tingginya jumlah permintaan tenun tidak sebanding dengan jumlah tenun yang tersedia di pasaran. Upaya ini selain dapat meningkatkan ekonomi masyarakat, secara tidak langsung juga dapat menjaga dan melestarikan warisan budaya yang menjadi ciri khas dan identitas masyarakat lokal. 

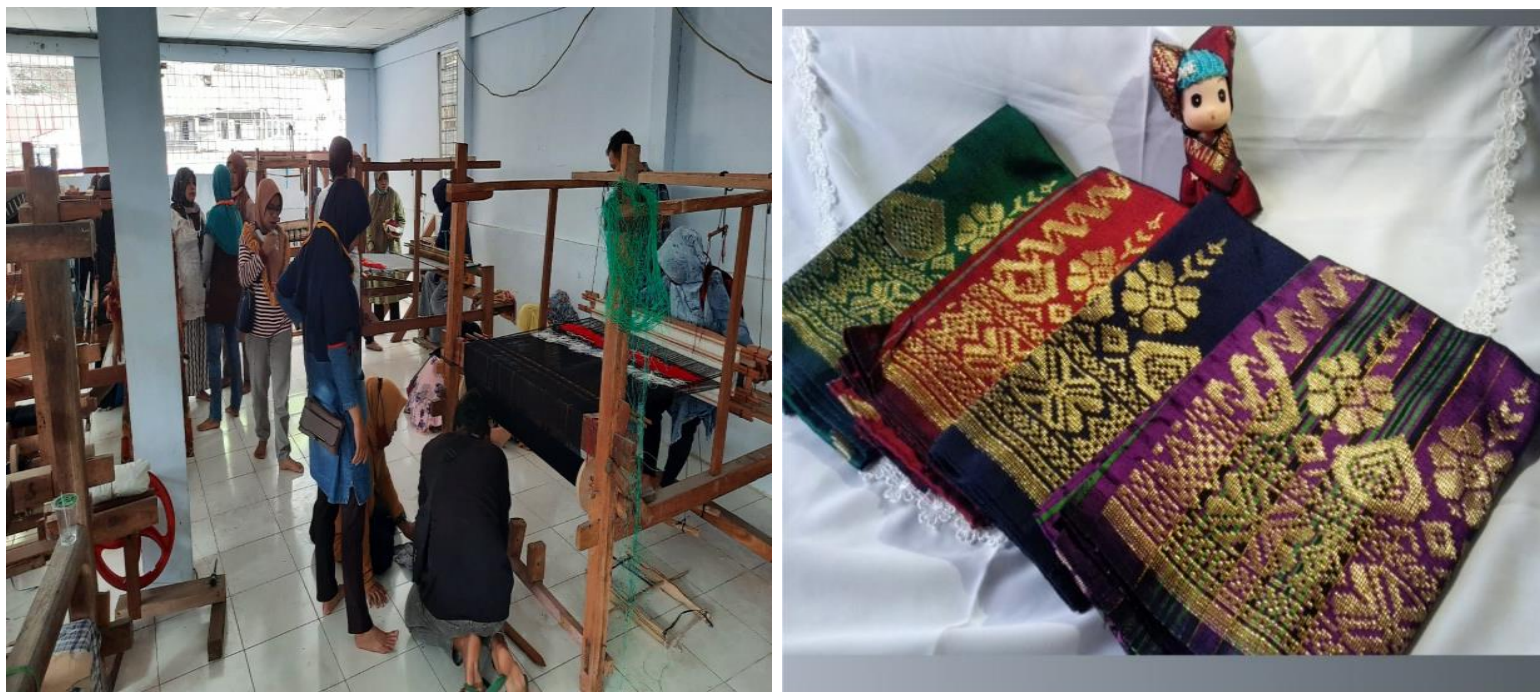

Gambar 1. Proses Pelatihan Tenun Songket dan Tenun Songket Hasil Pelatihan

Gambar di atas merupakan proses pelatihan dan hasil tenun songket yang dilakukan Dinas Koperindag kepada masyarakat. Pelatihan yang dilakukan selama 10 hari. Hasil yang didapatkan bukan saja keterampilan bagi masyarakat, tetapi juga sertifikat dan alat tenun songket yang terdiri dari plantai, sikek karok, turak, balero, bonang pakan bonang togak, dan buluah yang bisa dimanfaatkan oleh masyarakat untuk menjadi mata pencarian tetap nantinya sebagai upaya meningkatkan ekonomi rumah tangga mereka. Adapun tujuan Dinas Koperindag memberikan pelatihan tenun songket kepada masyarakat antara lain.

\section{Meningkatkan Ekonomi Pengrajin Tenun Songket}

Songket merupakan salah satu jenis tenunan tradisional yang ada di Sumatera Barat, salah satunya songket Silungkang. Pada umumnya songket dimanfaatkan untuk kegiatan resmi serta acara adat. Sehingga pangsa pasar songket tidak hanya mencakup lokal tetapi juga nasional. Untuk kisaran harga bisa dimulai dari Rp. 400.000., sampai Rp. 1.500.000. Tingginya harga sebuah kain tenun songket menjadi alasan utama masyarakat tertarik untuk mengikuti pelatihan tenun ini dan juga bisa menjadi mata pencarian yang cukup menjanjikan karena tingginya minat konsumen dipasaran terhadap kain tenun songket ini. Artinya secara tidak langsung masyarakat bisa meningkatkan perekonomian masyarakat yang khususnya bagi masyarakat Desa Muaro Kalaban.

Selain keterampilan yang diberikan, masyarakat juga mendapatkan bantuan alat tenun seperti plantai, sikek, karok, turak, balero, boning pakan, boning togak dan baluah. Bantuan yang diberikan dalam bentuk alat-alat bisa memudahkan masyarakat untuk meningkatkan ekonomi rumah tangga masing-masing. Secara tidak langsung bisa mengurangi angka kemiskinan di Kota Sawahlunto. Seperti yang diungkapkan oleh Asmardeni Kepala UPTD Tekstil Kota Sawahlunto, bahwa:

"Kami bekerja sama dengan pihak Koperindag dalam melaksanakan pelatihan tenun songket ini pada tahun 2012, kami ditunjuk oleh pihak bidang industri Dinas Koperindag Kota sawahlunto untuk memberi pelatihan dan fasilitas terhadap masyarakat yang melakukan suatu pelatihan yang bertempat di Desa Muarokalaban. Tujuannya agar ibu-ibu bisa berdikari melalui kerajinan tenun ini. Setiap dua bulan sekali, kami akan meninjau sejauh mana masyarakat bisa menghasilkan kain tenun songket Silungkang. Bantuan ini diberi dari Dinas Koperindag kepada masyarakat yang sudah memalalui proses pelatihan. Dan kami juga membantu masyarakat yang kesulitan dalam memasarkan kain songket hasil

Jurnal Socius: Journal of Sociology Research and Education Vol. 8, No. 2, Th. 2021 
tenun sehingga tidak ada hambatan untuk masyarakat untuk menghasilkan kain tenun (Wawancara, Desember 2020).

Pada dasarnya tujuan Dinas Koperindag memberikan pelatihan kepada masyarakat agar bisa berdikari sendiri dengan menghasilkan kerajinan songket. Nilai ekonomis yang terkandung dalam tenun songket membuka peluang bagi masyarakat untuk meningkatkan kesejateraan ekononomi. Hal ini terbukti hasil evaluasi terhadap pelatihan yang sudah diberikan kepada masyarakat dimanfaatkan oleh mereka untuk membuka usaha tenun sendiri. Sejalan dengan pendapat (Maryani, 2019) bahwa suatu keberhasilan sebuah program atau kegiatan tidak hanya ditentukan oleh pihak yang melaksanakan progam/pemberdayaan akan tetapi juga pihak yang diberdayakan untuk mengubah situasi dan kondisi mereka untuk menjadi lebih baik.

\section{Upaya Meningkatkan Produksi Songket Silungkang}

Upaya memberikan pelatihan kepada masyarakat oleh Dinas Koperindag dan UPTD Tekstil Kota Sawahlunto karena minimnya pengrajin tenun songket serta tingginya permintaan kain tenun songket dipasaran. Pelatihan ini pada awalnya dilaksanakan sejak tahun 2012 dan masih bertahan hingga sekarang. Selain membekali masyarakat dengan keterampilan menenun, mereka juga diberikan alat-alat tenun yang lengkap. Tujuanya agar masyarakat bisa melakukan produksi sendiri.

Hasil pelatihan yang diberikan kepada masyarakat membuat jumlah pengrajin songket meningkat, otomatis jumlah produksi dan penjualan juga meningkat cukup pesat. Pelatihan yang diberikan juga membuat masyarakat memproduksi songket dengan berbagai macam jenis. Pada awalnya produksi songket hanya terbatas pada sarung dan kain saja. Akan tetapi sekarang sudah sudah merambah ke produksi jenis lainnya seperti gambar dinding, taplak meja, permadani bergambar, baju wanita, sprey, baju kursi, bantal permadani, selendang, kain lap dapur, sapu tangan, bahan kemeja, taplak meja bahkan masker. Seperti gambar 3 dibawah ini.
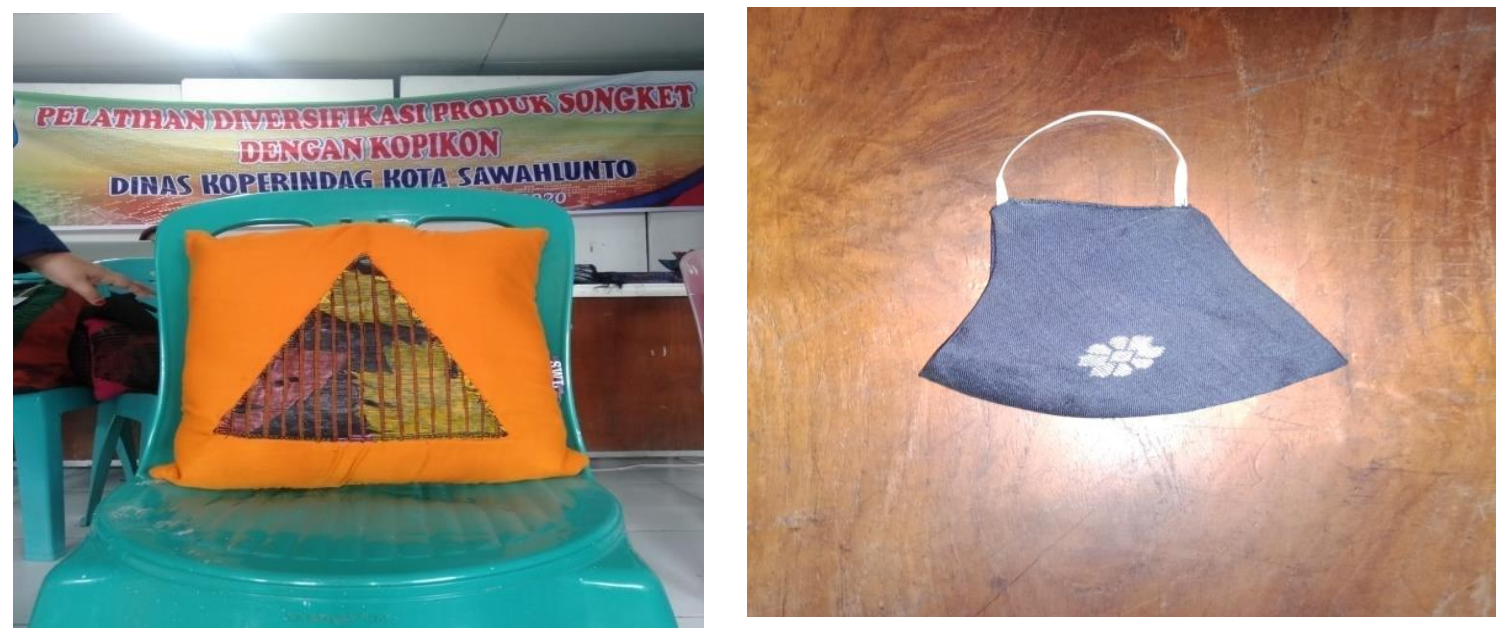

\section{Gambar 3. Produksi songket dikreasikan menjadi sarung bantal dan masker}

Selain di produksi dalam berbagai bentuk kreasi. Kerajinan tenun songket juga identik dengan berbagai macam motif. Biasanya motif tenun songket diberi nama tumbuh-tumbuhan, binatang ataupun benda-benda yang ada di alam. Beberapa ragam motif dari Nagari Silungkang antara lain adalah: bungo malur, pucuak ranggo patai, kudo-kudo, pucuak jawa, pucuak kelapa, tigo belah, kain balapak gadang, bungo kunyik, kaluak paku, sisiak dan lain lain. 
Sedangkan untuk hiasan tepi kain terdapat beberapa motif seperti "bungo tanjuang, lintahu bapatah, itiak pulang patang, bareh diatuah, ula gerang, dan lain lain.

Salah satu motif yang terkenal yaitu "pucuak rabuang" rebung dianggap sebagai tumbuhan yang sejak kecil sudah berguna bagi masyarakat. Sewaktu rebung masih kecil dapat digunakan sebagai bahan sayuran. Ketika sudah tumbuh besarpun masih tetap berguna sebagai contoh seperti bamboo sebagai alat bahan bangunan dan sebagainya. Motif ini tentunya diharapkan akan berguna pula bagi masyarakatnya yang memakai motif ini akan berguna pula bagi masyarakatnya.

\section{Melestarikan Karya Seni}

Kota Sawahlunto biasa di sebut dengan kota wisata tambang yang berbudaya dimana wisata tambang batu bara menjadi ciri khas dari kota ini. Selain wisata tambang, budaya tenun songket Silungkang juga merupakan salah satu ciri khas dari Kota Sawahlunto. Kain songket menjadi simbol bagi masyarakat Kota Sawahlunto yang memakainya. Ciri khas kain songket Silungkang terlihat pada keistimewaan tenunnya yakni benang pakan (benang hias). Pada bagian buruk kain songket, benang pakannya terlihat merentang dan tidak putus-putus, sehingga pada bagian baik kain songket benang pakan terlihat lebih menonjol dibanding dengan benang lusi/benang dasar (Utami, 2016).

Pada kain songket juga mengandung nilai-nilai yang menjadi acuan bagi kehidupan masyarakat sehari-hari. Adapun nilai-nilai yang terkandung didalam kain songket antara lain: nilai keindahan, kesakralan, ketekunan, ketelitian dan kesabaran. Untuk nilai keindahan terdapat dalam berbagai macam motif yang ada. Pada nilai kesakralan bisa kain songket bisa ditemukan pada peristiwa-peristiwa dan kegiatan penting terkait dengan upacara, seperti perkawinan, upacara batagak gala (penobatan penghulu). Sedangkan nilai untuk ketekunan, ketelitian dan kesabaran tergambar pada proses pembutannnya yang membutuhan ketekunan, ketelitian dan kesabaran. Tanpa unsur nilai tersebut tidak akan menghasilkan tenun songket yang bagus.

Untuk tetap melestarikan karya seni tenun songket, Pemerintah Kota Sawahlunto juga sering mengadakan event besar yang bertemakan kain tenun songket. Salah satunya acara tahunan Sawahlunto Internasional Songket Carnaval (SISCA) dimana acara ini diadakan supaya menjaga kelestarian dari kain tenun songket itu sendiri. Aktifnya pemerintah untuk tetap mempetahankan budaya tenun songket juga tergambar dalam pelatihan yang diberikan kepada masyarakat. Adapun sasaran pelatihan bukan saja kepada ibu-ibu rumah tangga tetapi juga kepada remaja. Tujuannya mereka mengenal dengan nilai budaya yang sudah ada sejak zaman dahulu serta tidak terkikis oleh fashion yang dating dari luar. Seperti yang diungkapkan Liza, menurutnya;

"Di era milenial ko sangek penting untuk kito manjago kebudayaan kito yang salah satunyo yang ado di desa kito ko yaitu kain tenun songket. Budayo kito ko jan sampai tenggelam ditelan tren tren fashions luar yang justru labiah diminati dek urang banyak khususnyo anak muda zaman kini. Mako dari itu ambo ikuik pelatihan tenun ko bertujuan ikuik serta melestarikan budayo tenun songket ko sehinggo cirri khas dari tampek kito ko terjaga tarui kelestarianyo (Dalam Bahasa Daerah Minangkabau).

\section{Artinya:}

"Di era milenial ini sangat penting bagi kita untuk menjaga kebudayaan kita yang salah satunya yaitu kain tenun songket, budaya kita ini jangan sampai tenggelam ditelan oleh tren tren fashions luar yang justru banyak diminati oleh masyarakat banyak khusunya anak muda zaman sekarang ini. Maka dari itu saya ikut pelatihan 
tenun ini bertujuan ikut serta dalam melestarikan budaya tenun songket ini sehingga ciri khas desa kita ini bisa terjaga kelestarianya (Wawancara, Desember 2020).

Penuturan informan di atas sangat jelas bahwa salah satu tujuan masyarakat mengikuti pelatihan tenun songket adalah untuk melestarikan songket sebagai salah satu karya seni yang menjadi warisan berharga dari leluhur masyarakat Sawahlunto. Tenun dalam hal ini dianggap bukan hanya memiliki nilai ekonomis, tetapi juga nilai estetika yang menjadi kebanggaan masyarakat setempat. Meningkatkan kemampuan masyarakat dalam menenun, sama halnya dengan memperkuat kelestarian warisan budaya masyarakat lokal.

\section{Strategi Pemasaran Kain Songket oleh Masyarakat}

Strategi pemberdayaan masyarakat pada hakekatnya sama dengan rencana yang cermat dalam pembangunan sumber daya manusia (SDM) didalam suatu organisasi atau perusahaan. Arti pembangunan itu sendiri adalah perubahan menuju kearah yang lebih baik. Hakekatnya pemberdayaan masyarakat adalah untuk meningkatkan kemampuan dan kemandirian masyarakat dalam meningkatkan taraf hidupnya (Handini, 2019). Seperti pelatihan yang diberikan oleh Dinas Koperindag dan UPTD Tekstil Kota Sawahlunto sebagai sebuah pemberdayaan masyarakat yang bertujuan menciptakan masyarakat yang mampu berdaya mandiri. Hasil kain songket yang diproduksi oleh masyarakat diharapkan mampu bersaing dan dikenal oleh masyarakat luas. Oleh sebab itu masyarakat perlu melakukan berbagai strategi dalam pemasaran kain songket. Berikut strategi pemasaran yang dilakukan oleh masyararakat.

\section{Membangun Relasi dengan Toko Grosir}

Salah satu strategi yang dilakukan oleh masyarakat untuk memasarkan kain tenun songketnya yaitu dengan cara membangun relasi dengan pedagang pedagang toko grosiran yang ada di Silungkang. Tujuannya agar produk kain songket yang dibuat oleh pengrajin ini bisa lansung terjual. Jika tidak adanya relasi antar pengrajin tenun dengan pemilik toko grosiran maka pengrajin akan kesulitan memasarkan kain songketnya tersebut.

Relasi yang dibangun salah satunya dengan menjual hasil produksinya kepada toke kain (pengumpul) yang ada di daerah Silungkang. Mereka nantinya yang akan memasarkan hasil kain songket ke daerah Sumatera Barat, luar provinsi bahkan keluar negara. Selain itu pengrajin juga memasarkan ke toko-toko songket besar seperti ANJ, AINA. Seperti yang diungkapkan oleh Desri Yunita, bahwa:

"Strategi yang ambo lakukan untuk manjua kain songket yang ambo buek ko yaitu dengan caro manjua nyo ka toke kain tonun nan beko kain ko di jua kalua daherah dan kalua Indonesia kayak malaysia, dan ambo jugo manjua kain ambo ka toko toko songket gadang contoh nyo ka toko arena songket INJ, AINA" (Dalam Bahasa Daerah Minangkabau).

Artinya:

"Strategi yang saya lakukan untuk memasarkan kain songket yang saya buat yaitu dengan cara menjualnya ke toko-toko songket besar contoh toko arena songket INJ, AINA dll (Wawancara, Desember 2020).

Hal yang sama juga diungkapkan Desri Murti, menurutnya:

“Ambo ko punyo toke yang biasonyo nan mamboli kain kami ko yang biasonyo dijua ka medan yang mano beko kain kami ko di opor ka medan atau ka malaysa selain itu ambo pun kadang manjua kain ka toko sonket INJ ataupun AINA karno kok awak ndk punyo relasi dalam memasarkan kain ko payahh awak di buek nyo 
mako dari itu ambo sabagai petenun songket ko harus punyo toke untuk membantu pemasaran kain tonun songket ambo ko" (Dalam Bahasa Daerah Minangkabau).

Artinya:

"Saya mempunyai toke atau biasanya yang jadi pengepul kain kami yang mana akan dijual ke Medan ataupun ke Malaysia selain itu saya juga menjual kain songket saya ke toko songket seperti toko INJ ataupun AINA karna klu kita tidak punya relasi dalam pemasaran songket ini maka kita akan kesulitan dalam pemasarannya (Wawancara, Januari 2021).

Data di atas memperlihatkan bahwa strategi penenun dalam memasarkan produk mereka adalah dengan cara menjalin relasi dengan toko besar/ grosir yang ada di Sawahlunto. Upaya ini mereka lakukan agar produk yang mereka hasilkan langsung dapat ditampung oleh toko besar untuk kemudian dipasarkan, baik ke pasar lokal amupun pasar global. Hal ini karena Tenun Silungkang saat ini tidak hanya dinikmati oleh masyarakat Sumatera Barat saja tetapi juga diminati oleh masyarakat mancanegara. Tenun songket menjadi salah satu souvenir andalan dari Sawahlunto. Seiring dengan semakin bertambahnya minat wisatawan ke Sawahlunto, maka bertambah pula permintaan tenun Silungkang, sehingga berdampak pada peluang usaha dan pendapatan masyarakat lokal.

\section{Pemasaran Secara Online}

Di era digital seperti saat ini sangat memudahkan komunikasi manusia, salah satunya di bidang pemasaran. Kondisi ini juga dimanfaatkan oleh pengrajin tenun yang memasarkan produk tenun songketnya melalui media sosial. Tujuannya akan memudahkan pengarajin untuk memasarkan produk songketnya secara luas untuk mendapatkan keuntungan. Apalagi konsumen lebih gemar untuk berbelanja secara online dibandingkan datang ke tokonya langsung.

Media sosial yang biasa digunakan untuk memasarkan produk kain songket ini yaitu, market place (Shopee, Toko Pedia dll), tidak hanya itu akun Facebook, Instagram, WhatsApss juga biasa digunakan sebagai media promosi untuk produk kain songket itu. Adapun jenis konten yang terdapat dalam media sosial seperti dalam bentuk foto, video dan teks biasa. Penggunaan video, foto dan teks biasa digunakan dalam bentuk Facebook dan Instragram. Sedangkan untuk konten foto dan teks biasayanya digunakan oleh masyaakat pada aplikasi WhatsApss. Artinya pada era digital saat ini memudahkan pengrajin memperkenalkan kain songket pada masyarakat luas. Seperti yang diungkapkan oleh Liza Adriani berikut ini.

"Di era mileneal kayak ko sangek penting bagi kito menjago kebudayaan kito salah satunyo kain songket. Karno sebagai generasi mudo yang bisa manjago budaya kito ko jan sampai tenggelam ditelan tren tren luar yang justru labiah diminati dek urang urang banyak, mako dek itu ambo nio baraja bertenun ko supayo bisa berkreasi sekreatif mungkin untuk menarik konsumen bahwa kain tenun ko indak kalah rancak dibandiang tren tren fasions lainnyo. Strategi yang dilakukan untuk manjua kain songket di era milenial ko tidak lah sulit, kini lah ado nan namonyo media social kayak shopee, toko pedia, facebook, instragram, wa serta market place lainnyo, karno ambo raso urang urang kini ko lobiah suko balanjo sacaro online, (Dalam Bahasa Daerah Minangkabau). 


\begin{abstract}
Artinya:
"Di zaman milenial seperti sekarang sangat penting bagi kita menjaga kebudayaan kita yaitu salah satunya kain tenun songket. Karna sebagai generasi muda yang bisa menjaga kelestarian budaaya kita ini jangan sampai tenggelam oleh tren-tren luar yang justru lebih diminati oleh masyarakat. strategi yang saya lakukan untuk memasarkan kain songket di era milenial ini tidak lah sulit, sekarang sudah ada yang namanya media sosial seperti Shopee, Toko Pedia, Facebook, Instagram, WA dan market place lainya, karena saya berfikiran bahwa masyarakat lebih cendrung berbelanja secara online (Wawancara, Januari 2020).
\end{abstract}

Terkait dengan pemberdayaan yang dilakukan oleh Dinas Koperindag dan UPTD Tekstil Kota Sawahlunto melalui pelatihan tenun songket dengan tujuan meningkakan ekonomi masyarakat. Pembahasan ini dengan menggunakan skema AGIL Tarcot Parson (Ritzer, 2010). Untuk Adaptasi (Adaptation) dimana Dinas Koperindag dan UPTD Tekstil sukses melaksanakan pelatihan tenun songket berdasarkan kebutuhan dari masyarakat. Pada dasarnya kebutuhan yang diinginkan oleh masyarakat adalah sebuah lembaga keuangan mikro yang mampu membantu mereka dalam memenuhi kebutuhan hidupnya serta memudahkan masyarakat khususnya ibu rumah tangga untuk meningkatkan perekonomiannya.

Kemudian dari segi Integrasi, kemampuan Dinas Koperindag dan UPTD Tekstil berhubungan dengan baik di tengah masyarakat maupun antar bidang pengelola pelatihan itu sendiri. Sehingga mampu mendorong peningkatan pendapatan dari pengrajin tenun songket itu sendiri. Sedangkan fungsi Goal Attainment tergambar dari tujuan dilakukan pelatihan songket ini yaitu untuk mengentaskan masyarakat dari kemiskinan. Pada fungsi Latency yaitu memberikan pengawasan serta melakukan evaluasi kinerja dari peserta pelatihan tenun songket. Selain itu juga dengan cara melakukan promosi-promosi melalui media cetak seperti brosur-brosur, spanduk dan juga mengadakan acara besar sperti SISCA (Sawahlunto Internasional Songket Carnaval).

\title{
Simpulan
}

Berdasarkan penelitian ditemukan bahwa pemberdayaan pengrajin tenun Silungkang dilakukan dalam bentuk memberikan pelatihan yang dilakukan oleh Dinas Koperindag Bidang Industri dan UPTD Tekstil Kota Sawahlunto. Pelatihan ini bertujuan untuk meningkatkan ekonomi pengrajin songket, meningkatkan produksi songket Silungkang serta melestarikan karya seni. Pemberdayaan ini faktanya mampu meningkatkan produktivitas pengrajin songket serta meningkatkan jumlah produksi tenun Silungkang, sehingga dapat memunuhi permintaan pasar. Sementara itu untuk meningkatkan perekonomian mereka pengrajin tenun berupaya untuk memasarkan produk yang mereka hasilkan dengan menetapkan beberapa strategi, diantaranya; membangun relasi sosial dengan toke dan pedagang di sekitar Silungkang serta memasarkan hasil produksi secara online melalui media sosial. Upaya ini nyatanya mampu meningkatkan perekonomian mereka, sehingga tenun Silungkang menjadi sumber mata pencarian yang dapat diandalkan oleh masyarakat Sawahlunto. 


\section{Daftar Pustaka}

Afrizal, A. (2008). Pengantar Metode Penelitian Kualitatif. Padang: Laboratorium Fisip Unand.

Amadani, S. (2015). Kendala Kendala Pada Industri Kerajinan Tenun Songket Unggan Di Nagari Unggan Kecamatan Sumpur Kudus Kabupaten Sijunjung. STKIP PGRI Sumbar.

Arikunto, S. (2006). Prosedur Penelitian Suatu Pendekatan dan Praktek. Jakarta: Rineka Cipta.

Denzin, N. K., \& Lincoln, Y. S. (2009). Handbook of Qualitaive Research. Yogyakarta: Pustaka Pelajar.

Efendi, H. (2019). Peranan Industri Songket Dalam Meningkatkan Pendapatan Rumah Tangga Pengrajin di Nagari Halaban Kabupaten Lima Puluh Kota. JISPO Jurnal Ilmu Sosial dan Ilmu Politik, 9(2), 159-169.

Handini, M. M., \& Sukesi, S. (2019). Strategi Pemberdayaan Masyarakat Desa dalam Upaya Pengembangan UMKM Wilayah Pesisir. Universitas Budi Utomo.

Harsari, H. (2018). Pembinaan Sentra Produksi Tenun Songket Unggan Oleh Pemerintahan Kabupaten Sijunjung. Jurnal Ilmu Administrasi Publik, 1(1).

Mardatillah, A., Rosmayani, R., \& Ramadhani, S. A. (2020). Sustainable Competitive Advantage of Riau Malay Weaving Industry Based on Local Wisdom. International Research Journal of Business Studies, 13(3), 227-240. https://doi.org/10.21632/irjbs.13.3.227-240

Maryani, R. (2019). Pemberdayaan Masyarakat.

Ritzer, G. (2010). Teori Sosiologi Modern. Jakarta: Kencana Prenada Media Group.

Rodgers, S. (2007). Gold Cloths of Sumatra: Indonesia's Songkets from Ceremony to Commodity. Cantor Art Gallery. Worcester. Massachusetts.

Sugiyono. (2012). Metode Penelitian Kuantitatif Dan R\&D. Bandung: Alfabeta.

Syafrini, D., Nurdin, M. F., Sugandi, Y. S., \& Miko, A. (2021). Transformation of a Coal Mining City into a Cultured Mining Heritage Tourism City in Sawahlunto, Indonesia: A Response to the Threat of Becoming a Ghost Town. Tourism Planning and Development, 18, 1-20. https://doi.org/10.1080/21568316.2020.1866653

Utami, O. R. (2016a). Studi kain songket silungkang. Jurnal Komunikasi Dan Kebudayaan, 2(1).

Utami, O. R. (2016b). Studi Kain Songket Silungkang. Jakarta: UNJ

Wijaya, N. (2017). Perancangan Aplikasi Promosi Songket Palembang Berbasis Android. Jurnal Sistem Informasi Musirawas, 2(2), 74-85. 